ideal summary of work dispersed throughout a multitude of different publications.

\section{Aerial Surveys for Town Planning}

THE urgent necessity for modern town plans required under the Town Planning Act has raised the possibility of meeting the demand by aerial survey. In most cases, less than two years remain for the completion of these plans. The Ordnance Survey at its existing strength cannot hope to meet this demand. A scheme outlined in the Times of May 5, however, promises to meet the situation, and the Ordnance Survey has promised its co-operation if local authorities make immediate revisions by air survey. The scheme would admit of the 16,000,000 acres of town planning areas in England and Wales being covered within two years. The country would be divided into sixteen units, of which eight would be photographed concurrently. On the reasonable assumption that 30 days in the year would be suitable for vertical photography, the work could be done in the two years available. Local authorities would be supplied with prints on a scale of $1: 5000$ and a set of transparencies on the same scale as the Ordnance sheets. The originators of the method are Messrs. H. Hemming, Ltd., and Economic Air Surveys, Ltd. The fully revised Ordnance sheets would follow later.

\section{Aerial Surveys in the United States}

AN extended scheme of aerial mapping in the southern States is planned under the United States Geological Survey in co-operation with the Shore and Geodetic Survey, the Census Bureau and other Federal bodies. The area to be covered, according to a report issued by Science Service, of Washington, D.C., is 40,000 square miles, selected from agencies in the States of Alabama, Arizona, Arkansas, California, Georgia, Louisiana, Mississippi, New Mexico, South Carolina, Texas and the District of Columbia. The maps will be used primarily in connexion with the agricultural census to be made in November next, but will have a permanent use as State records and for other purposes. The need for a more systematic land survey is indicated by the fact that air reconnaissances have already revealed the existence of vacant farms and waste lands not under cultivation hitherto unrecorded and consequently in some instances escaping taxation. There may be an extension of the scheme later to cover 1,000,000 square miles. As at present planned, it will take seventy days to complete at a cost of 650,000 dollars. The aeroplanes will have the cooperation of link-men on the ground under observation, and altogether 500 engineers with 1,500 assistants will be employed. The scheme is part of the programme of the Civil Works Administration for the relief of unemployment.

\section{Records of the Maya}

STUDENTs of American archæology will welcome the publication by the Carnegie Institution of Washington of "The Book of Chilam Balam of Chumayel" - the Book of Balam the Prophet, which, giving an account of certain matters pertaining to ritual and belief as recorded by the ancient Maya in their own language, is one of the most important pieces of documentary evidence relating to the early history of Yucatan known to scholars. The book has been edited by Mr. Ralph L. Roys, who for the first time has applied the principles of classical scholarship to the establishment of a standard text. The text is accompanied by a translation and annotations by the editor. There are several versions of the Book of the Prophet Balam, each known by the name of the village to which it belonged originally, such as that of Tizimin, Ixil, or Nah. That of Chumayel, with those of Tizimin and Mani, have the greatest value for the study of Maya civilisation. Chilam Balam, whose prophecies are recorded among the matter in his book, lived at the end of the fifteenth century and the beginning of the sixteenth. The Chumayel version dates only from 1782; but there is little doubt that the greater part of it has a pedigree as an authentic copy going back to the sixteenth century when the Maya wrote down in the European script, but in their own language, prophecies, chronicles, rituals, myths, calendrical matter and medical treatises, much of which would appear to have been transcribed directly from the hieroglyphic manuscripts afterwards destroyed and proscribed by the Spaniards. The original manuscript of the Chumayel version has disappeared, and the present text has been prepared from photographic copies.

\section{Nature Sanctuaries in Zululand}

Natal possesses five sanctuaries for wild life, and all, with the exception of the bird sanctuary at St. Lucia and False Bay, have special interest on account of the rare mammals they contain-the Umfolosi has the only surviving herd of the southern white rhinoceros. The reserves have been threatened to some degree because of the fear that their mammals preserved a reservoir of the trypanosomes of the cattle disease, nagana. But it may be accepted that the destruction of big game is a futile method of controlling the tsetse-borme disease, and that the reserves may well be retained, since they occupy areas unfitted for agriculture on account of endemic nagana, malaria, insufficient rainfall or poverty of soil. Indeed, in a pamphlet on "Natal's Nature Sanctuaries in Zululand" E. K. du Plessis urges that they should be properly established and made statutory, that they should be provided with suitable approaches to encourage tourist traffic, and that they should be surrounded by a three-mile buffer-zone, to prevent shooting parties from slaying animals on the very border of the reserve. It is further suggested that the shooting season should close at the end of September, since the does are in young by October, and that all-year licences for shooting should be discontinued.

\section{Lancashire and Cheshire Fauna Records}

THE issue of the nineteenth annual report of the Lancashire and Cheshire Fauna Committee for the 